\title{
ABOUT THE UNIVERSAL TECHNOLOGY OF PROCESSING JERUSALEM ARTICHOKE AND CHICORY FOR INULIN
}

\author{
Tatyana S. Puchkova, Daniya M. Pikhalo*, Oksana M. Karasyova \\ All-Russian research Institute for Starch Products - Branch of V.M. Gorbatov Federal Research Center \\ for Food Systems of RAS, Kraskovo, Moscow Region, Russia
}

\section{KEY WORDS:}

girasol, chicory, inulin, diffusion, extract, purification, cation exchanger, anionite, carbohydrate composition

\begin{abstract}
The purpose of this work is development of the universal technology of processing of a girasol and chicory for an inulin according to requirements to quality of a feed stock. An inulin - the reserve carbohydrate widespread in flora. There is the most of inulin quantity in chicory, a girasol, much less is in onions, garlic, inula, yakena, etc. The inulin is widely applied as a low-calorie product in a dietary and diabetic food, just also as a jelly former in food. In the All-Russian Research Institute of Starch Products there are conducted researches on development of the universal technology for an inulin from inulin-containing raw materials. The technological assessment of a girasol and chicory from various regions of the Russian Federation is carried out, their physical and chemical indexes are defined. Requirements to processing behavior of raw materials are developed for inulin processing. By results of researches initial requirements to inulin-containing raw materials are defined: a mass fraction of dry solids is not less than $25 \%$, an inulin is not less than $16 \%$; mono - and disaccharides are $2 \%$. Diffusion from freshly harvested and dry chicory shavings and a girasol is studied, optimal established conditions are temperature $80-85^{\circ} \mathrm{C}$; the hydromodule for dry shaving $-1: 7$; for crude one $-1: 2$. It is developed the purification mode for extract and girasol and chicory syrups with use of various adsorbents such as the fissile coal, ion-exchange resins. The established high extent of extract and syrup purification is resulted in considerable decrease in a chromacity, mass fraction of a protein, ashes, etc. For researches as control specimens there was used an inulin of the foreign companies. Significance of the work is the creation of domestic technology of an inulin as prebiotic component for a treatmentand-prophylactic nutrition of the population and ensuring its import substitution.
\end{abstract}

\section{Introduction}

The perspective direction of development of the food industry is production of products of the functional purpose on the basis of the nonconventional types of vegetable raw materials having specific properties and chemical composition. Inulincontaining tubers of a girasol and root crops of chicory belong to such type of vegetable raw materials. An inulin is the most extended natural polysaccharide which after starch. It is a reserve energy source of many plants. Most of all inulin contains in chicory, a girasol, it is much less in such plants as onions, garlic, inula, yakon and others. The mass fraction of an inulin in chicory and a girasol slightly differs and averages $14-18 \%$. At the organization of an inulin production it is necessary to consider features of these cultures in an agrotechnology, ways of storage and processing [1]. So, a Russia girasol is a more widespread culture, but chicory is easier to be processed thanks to a convenient form of its root crops, but existing glycoside of the intibin gives a bitter taste to chicory and demands additional purification.

The inulin has unique physiological properties therefore it is necessary to use it first of all as a product of the functional purpose, and it is soluble food fiber, helps to decrease a level of cholesterin, doesn't influence glucose level in blood therefore it is used in a diet of diabetic patients. The inulin increases digestibility of calcium, iron and magnesium, prevents development of osteoporosis. Thanks to the prebiotic properties it passes in an invariable state to a large intestine where it increases the contents of the useful bifidobacteria and inhibits influence of harmful pathogenic bacteria [2, 3]. The inulin and its derivants are applied in the food industry to improve nutritious and functional properties of products, they are also used as fat substitute to decrease caloric content of food [4]. All these specified properties of an inulin contributed to the broad development of researches on development of its technology.
In recent years in Western Europe and China inulin production increased in tens of times and makes more than 100 thousand tons per year now. The main producers of an inulin and its derivants from chicory are Beneo Orafti, Cosucra (Belgium) and Sensus (Holland), and from a girasol it is China. In Russia now production of an inulin is absent, it is only imported [1]. In many countries of the world and also in Russia the inulin is widely used as a food additive for bread and bakery products, dairy products, confectionery, products of baby food.

The purpose of this work was to develop of the universal technology of processing of a girasol and chicory for an inulin according to the requirements to quality of an initial product.

\section{Materials and methods}

As an object of researches there were used girasol tuber crops in accordance with GOST P 55757-2013 [5], chicory root crops to operating of normative documents, inulin-containing products such as the extract received by hot water extraction from freshly harvested or dry raw materials (a girasol and chicory) and also the syrup purified with the fissile coal and ion-exchange resins.

For researches an inulin from chicory and a girasol of the foreign companies were used as control samples. Ion-exchange purification of inulin-containing syrup was carried out according to two-level scheme $\mathrm{K} 1+\mathrm{A} 1+\mathrm{K} 2+\mathrm{A} 2$ under conditions: temperature $-20-35^{\circ} \mathrm{C}$; throughput rate $-1.0-2$ volumes of syrup from one volume of resin per hour.

In the syrup purified on ion-exchange resins there was defined $\mathrm{pH}$, chromaticity, protein and ash content, carbohydrate composition, an optical density in the UF-range and also transparency and taste (lack of a bitter taste). By results of researches it was calculated effect purification (E.P., \%) of the product from the main impurity (painting ashes and substances, protein) at various stages. 
When carrying out researches the following methods of the analysis and devices were used:

$\square$ a mass fraction of moisture - on the hygrometer MF-50 (the AND company, Japan);

$\square$ definition of a mass fraction of an inulin in inulin-containing raw materials - by the method developed in the All-Russian Research Institute of Starch Products;

$\square$ determination of carbohydrate composition of extract and syrup - on a liquid chromatograph of carbohydrates with the Gilson refractometer sensor;

$\square$ definition of an optical density of syrups - on a spectrophotometer SF 2000 (experimental design bureau «Spektr», St. Petersburg);

$\square$ definition of a chromacity of syrups - on a photometer KFK3 ;

$\square$ a mass fraction of protein by the Kyeldal method - on the device K-424 (the BUCHI Labortecknik company, Germany);

$\square$ determination of dry solids, ashes, $\mathrm{pH}$, etc. indexes - by the techniques accepted in starch syrup and beet sugar production [6].

\section{Results and discussion}

\subsection{Results}

In the All-Russian Research Institute of Starch Products there is conducted scientific research work on processing of inulin-containing raw materials - a girasol and chicory for an inulin. As a result of the conducted researches the most optimum sequences of processing methods of receiving an inulin and its derivants - oligofructose and fructose syrup are developed. The key universal flow diagram (Figure 1) of receiving an inulin and its derivants is given below.

According to the given flow diagram for receiving an inulin in the form of a concentrate with a mass fraction of an inulin of $85 \%$ and a powdery inulin with a mass fraction of an inulin of $95 \%$ it is necessary to use various ways of syrup purification. The universal technology of processing of a girasol and chicory for a concentrate and a powdery inulin is carried out accord- ing to the following scheme: purification, washing and scalding of raw materials; a refinement in shaving; diffusion; coagulation of impurity; mechanical filtering; purification with the fissile coal and ion-exchange resins; concentrating and drying. The powdery inulin with a higher extent of purification is received with use of additional ion-exchange cleaning, and also by nanofiltration or chromatography. The choice of technology depends on quality of the processed inulin-containing raw materials, the required purity of the end product and economic prerequisites $[7,8]$.

\subsection{Development of requirements to quality of inulin- containing raw materials to be processed for an inulin}

It is researched the influence of a high-quality factor of inulin-containing raw materials to be processed for an inulin by the following criteria: a mass fraction of dry solids in juice and shaving, a mass fraction of an inulin in extract, carbohydrate composition of raw materials, the size of a tuber or a root plant. Samples of the most perspective grades of a girasol to be processed for an inulin are provided to us by LLC VIVA (The Kostroma Region), and chicory of LLC Sovremennik (The Moscow Region). For carrying out researches there are chosen the raw materials samples containing: a mass fraction of dry solids - not less than $20 \%$; a mass fraction of an inulin not less than $14 \%$; a mass fraction of di - and monosaccharides - no more than $2 \%$. For definition of a mass fraction of an inulin in inulin-containing raw materials in All-Russian research Institute for Starch Products the technique based on stratographic and chemical analysis analysis is used. Results of the received researches (Table 1) on a mass fraction of an inulin are $14.05-18.51 \%$, and $\mathrm{di}-$ and monosaccharides - no more than $2 \%$.

Technological assessment of varieties of inulin-containing raw materials is of great importance and allows to specify requirements to quality of a girasol and chicory for receiving an inulin. By the results of technological assessment of various varieties of a girasol and chicory preliminary requirements to

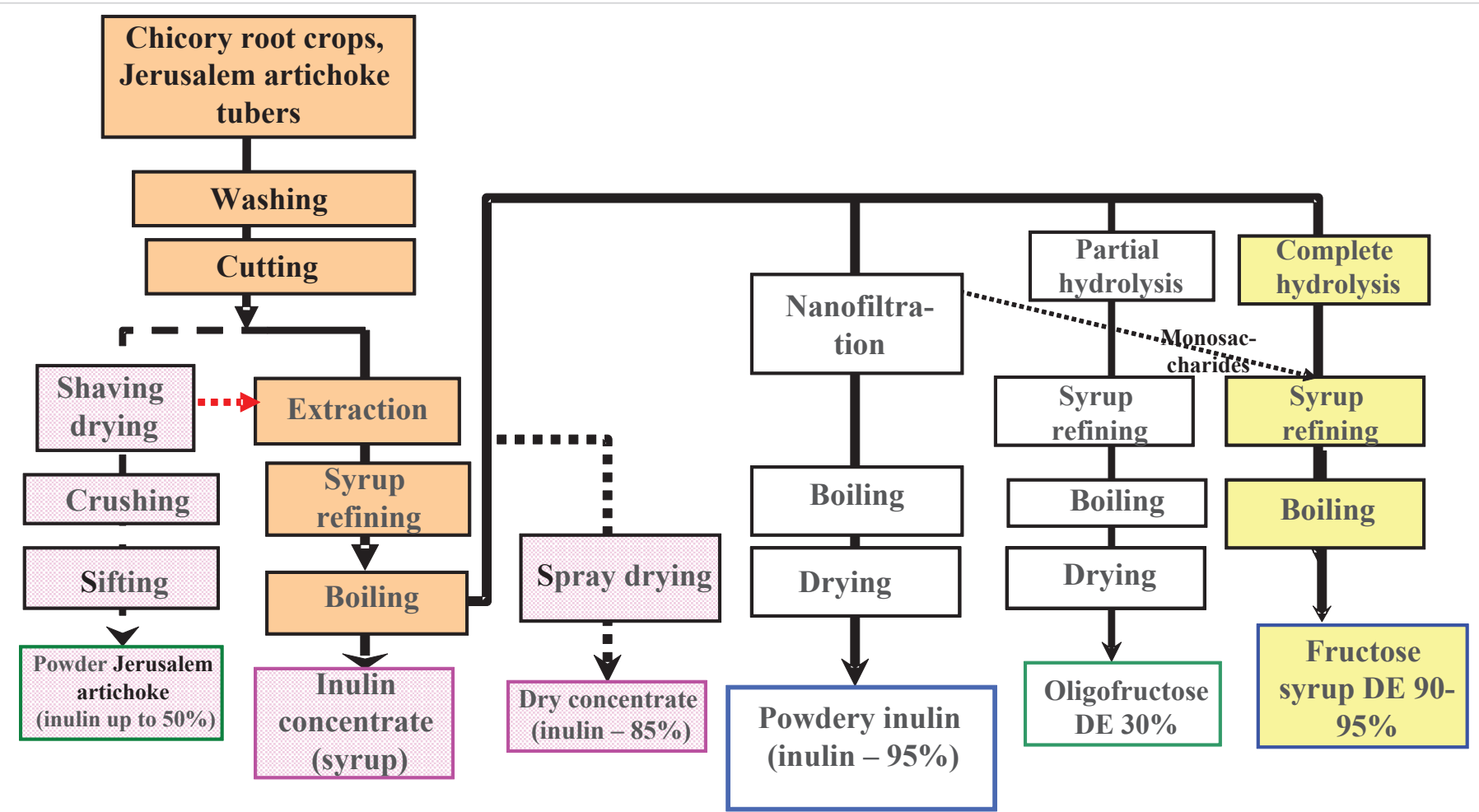

Figure 1. The key universal flow diagram of receiving an inulin and its derivants: concentrate; powdery inulin; inulin concentrate (syrup); inulin concentrate (powder); powdery inulin; oligofructose; fructose syrup 
Physical and chemical indexes of inulin-containig raw materials

\begin{tabular}{|c|c|c|c|c|}
\hline \multirow[t]{2}{*}{ Name of indexes } & \multicolumn{2}{|c|}{ Girasol, variety } & \multicolumn{2}{|c|}{ Chicory, variety } \\
\hline & Skorospelka & Skorospelka & Yaroslavsky & Aleksandrovsky \\
\hline Mass fraction of dry solids of juice, $\%$ & 19.72 & 24.8 & 20.4 & 21.0 \\
\hline Mass fraction of dry solids of raw materials, \% & 21.50 & 25.30 & 22.62 & 23.62 \\
\hline Mass fraction of insoluble matters (including fats), $\mathrm{g} / 100 \mathrm{~g}$ of raw materials & 3.15 & 3.78 & 5.05 & 4,10 \\
\hline Mass fraction of soluble matters $g / 100 \mathrm{~g}$ raw materials & 18,35 & 21,52 & 17,57 & 19.52 \\
\hline Mass fraction of carbohydrates, $g / 100 \mathrm{~g}$ of raw materials, including: & 16.76 & 19.92 & 16.80 & 19.52 \\
\hline- inulin & 14.05 & 18.51 & 15.65 & 16.57 \\
\hline - oligosaccharides & 0.85 & - & - & - \\
\hline - disaccharides & 1.86 & 1.41 & 0.98 & 2.01 \\
\hline - glucose & 0.0 & 0.0 & 0.0 & 0.0 \\
\hline - fructose & 0.0 & 0.0 & 0.17 & 0.48 \\
\hline
\end{tabular}

its selection and processing behavior are developed to processed for an inulin: a mass fraction of dry solids - not less than $25 \%$, an inulin - not less than $16 \%$; mono - and disaccharides $-2 \%[8]$.

\subsection{Preparation of inulin-containing raw materials for diffusion of an inulin}

For researches there are used tubers of a girasol and root plants of chicory and also their dry shaving. In the course of processing for an inulin the extract received from inulin- containing raw materials is influenced by medium with various acidity at increased temperature. High content of mono, - disaccharides and also impurity of not carbohydrate character - a protein, micro and macrocells in raw materials, a complex of own enzymes complicate the process of its purification, increase the content of the colored products of their disintegration that increases chromaticity of a product. Such combination of chemical composition of raw materials and extract and also conditions of the medium leads to the formation of colorants, products of carbohydrates decomposition and, as a result, to the decrease of an inulin yield. It is established the influence of own fermental system of raw materials on process of inulin selection. To prevent the increase in a products chromacity when processing raw materials, especially a girasol for an inulin, there are offered various ways of processing. Researches showed that a chromacity of extract from various anatomic parts of a girasol tuber of a widespread variety Skorospelka and also «Gorno-Altaysk» is lower when scalding, than without scalding [7,8]. Influence of tubers scalding on a chromacity of extract from anatomic layers of a girasol «Gorno-Altaysk» is presented in Figure 2.

It is established that a chromacity of extract from various anatomic layers of a girasol is distributed unevenly, and from the blanched tubers it is lower, than from not blanched. In this regard when processing a girasol for an inulin scalding of girasol tubers is a rational technology solution to improve quality of the end product and decrease adsorbents consumption for purification.

It is known that on air because of oxidation shaving of inulin-containing raw materials darkens. It is probably resulted in carbohydrates oxidation of raw materials in the presence of air oxygen by own fermental system with formation of colorants. To prevent colorants formation and an inactivation of own fermental system in the processed raw materials along with scalding there are used various chemical reagents such as lemon, acetic or ascorbic acids, sodium pyrosulphite. It is established that sodium pyrosulphite solution use for processing of crushed chicory and girasol shaving while processing and drying reduces its darkening. A chromacity of extract from the processed shaving is $30 \%$ lower, than the raw one, and the carbohydrate composition of the extract practically doesn't change in processing [8].

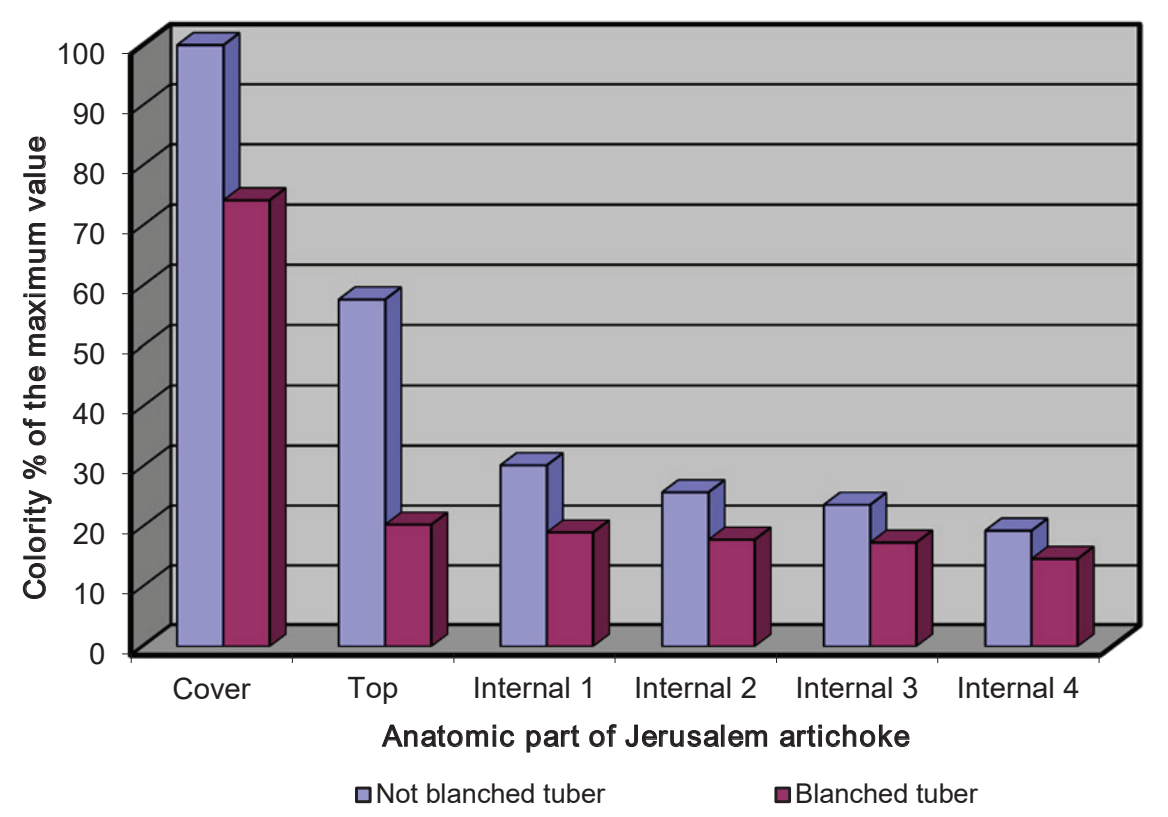

Figure 2. Chromacity of extract of anatomic layers of girasol tubers «Gorno-Altaysk» 
Thus, the accelerated processing of products is necessary to prevent the influence of air oxygen and own fermental system of raw materials on colorants formation and darkening of shaving when receiving an inulin.

\subsection{Diffusion of inulin-containing raw materials}

For receiving an inulin from inulin-containing raw materials it was used a method of hot water counterflow diffusion. To create the conditions for increasing an inulin yield and to minimize an impurity leaving the raw materials into extract it is necessary to optimize such parameters as temperature for increase in diffusion rate, hydromodule value, process time, crushing degree of raw materials.

When receiving an inulin it is possible to use two ways of crushing of inulin- containing raw materials: fine crushing on graters; as shaving by analogy to beet sugar production $[9,10]$.

More complete breaking of plant cells, perhaps, happens at a refinement by a grater followed by juice pressing or extraction. Its shortcoming is that from raw materials a large amount of the impurity forming colorants in extract gets to juice.

Cutting of inulin-containing raw materials to shaving of a channeled or platelet shape allows to solve this problem. At the same time the significant amount of impurity, undesirable to production, remains in shaving, and the mass fraction of an inulin in extract raises.

It is established that the optimum length of shaving $100 \mathrm{~g}$ of inulin-containing raw materials is $10-20 \mathrm{~m}$, at the same time the intensity of diffusion increases, however, as the length of shaving increases there is an increase in a chromacity of extract. There are received the equations of dependence of dry solids and a chromacity of extract from a crushing degree of raw materials, temperature and process time $[3,9]$. Optimum temperature of diffusion process $80-85^{\circ} \mathrm{C}$ lasting $60 \mathrm{~min}$. allows to receive extracts of the high inulin content and the minimum quantity of colorants.

The developed technological mode is the extraction of an inulin from inulin-containing raw materials is by hot water diffusion: the hydromodule of crude shaving makes $1: 2$, of the dry one is $1: 7$, temperature $80-85^{\circ} \mathrm{C}$, the optimum length of $100 \mathrm{~g}$ shaving is $10-20 \mathrm{~m}$.

The researches of the continuous hot water diffusion from shaving of inulin-containing raw materials resulted in the essence new design of a diffusion device having an inclined screw mechanism there is, and a patent No. 2643243 «The diffusion device of the continuous action» of 31.01.2018 taken out by the Russian Federation [11].

\subsection{Purification of extract}

Extract of inulin containing raw materials except carbohydrates contains the significant amount of mineral impurity and also protein compositions and other high-molecular substances of colloid character. It is established that these impurity efficiently are removed by acid coagulation, at $80-85^{\circ} \mathrm{C}$ and $\mathrm{pH}$ 4.5-4.7 followed by mechanical filtering [9]. It is defined that extract purification with defecosaturation (serial processing by suspension of lime hydrate and a carbon dioxide) can be carried out only from freshly harvested inulin containing raw materials. It is bound to the fact that when processing a girasol after the rewintering or chicory after the long-term storage for an inulin there is possible change of carbohydrate composition of raw materials, and in an alkaline medium at defecosaturation in extract there is a decomposition of fructosans, mono - and disaccharides that leads to formation of colorants and change of its carbohydrate structure [9].

Chicory extract, unlike girasol extract, has the bitter flavor caused by presence of a glycoside of an intibin in it. Its content in chicory is $0.032-0.099 \%$. It is established that at defecosaturation in an alkaline medium the bitter flavor of extract disappears that is an important factor when receiving an inulin [9]. Researches on purification of extract from freshly harvested root crops of chicory showed that after defecosaturation its chromacity and protein content decrease and change of carbohydrate structure isn't observed [6,7].

Thus, purification of the extract containing the significant amount oligo-, di - and monosaccharides when receiving an inulin, is necessary to be carried out only by acid and thermal coagulation, without defecosaturation.

For removal of soluble impurity and colorants the extract is processed with the fissile coal of the OU-B brand. Depending on quality of extract and a way of its receiving the coal consumption makes $2-4 \%$ to the mass of dry solids of extract, processing time is $20-30 \mathrm{~min}$. at $60-70^{\circ} \mathrm{C}$. The syrup purified with coal after filtering represents the transparent light yellow solution [7].

It is known that along with an inulin in raw materials there are di - and monosaccharides, nitrogenous substances, micro and macroelements. All these undesirable impurity, especially mono - and disaccharides, complicate purification process of extract and syrup because of increase in a chromacity of a product. In this regard for the following purification ion-exchange resins were applied to achieve high purity, more complete demineralization and to remove protein from inulin-containing syrup.

Due to the lack of domestic production of ion-exchange resins inulin-containing were purified syrups with the Purolite resins (USA). The following brands of ion-exchange resins (Table 2) were tested: strong acid cation exchanger C150, a weak-basic anionite A103S, strong acid cation exchanger PPC $150 \mathrm{~S}$ and a strong-basic anionite A510SMB Plus (for cleaning in the mixed bed) and also Makronet's sorbents MN-150, MN-200 and MN-502.

Table 2

Characteristic of ion-exchange resins of the Purolite company

\begin{tabular}{|c|c|c|c|c|c|}
\hline Resin grade & Ionic form & $\begin{array}{l}\text { The aggregate exchange } \\
\text { capacity, g-e/l }\end{array}$ & $\begin{array}{l}\text { Bulk weight, } \\
\text { g/l }\end{array}$ & $\begin{array}{l}\text { Humi-dity, } \\
\%\end{array}$ & $\begin{array}{l}\text { Specific gravity of the } \\
\text { damp grains, } g / \mathrm{ml}\end{array}$ \\
\hline C150S cation exchanger & Strong acid $\mathrm{Na}^{+}, \mathrm{H}^{+}$ & 1.8 & $785-825$ & $48-53$ & 1.25 \\
\hline Anionite & Weak-basic $\mathrm{OH}^{-} \mathrm{Cl}^{-}$ & 1.5 & $645-675$ & $53-58$ & $1 / 04$ \\
\hline A103SPlus & Weak-basic $\mathrm{OH}^{-} \mathrm{Cl}^{-}$ & 1.5 & $645-675$ & $53-58$ & 1.04 \\
\hline Anionite & Weak-basic & 1.8 & $770-810$ & $48-53$ & 1.25 \\
\hline A103S & Strong-basic $\mathrm{OH}^{+}$ & 1.15 & $680-715$ & $48-56$ & 1.08 \\
\hline PPS 150 Plus cation exchanger & Neutral & - & 670 & $59-53$ & 1.04 \\
\hline Plus A510SMB anionite & Strong-basic $\mathrm{OH}-, \mathrm{C} 1-$ & 0,25 & - & $50-52$ & - \\
\hline Makronet's sorbent of MN-200 & Strong acid $\mathrm{H}^{+}$ & $0.8-1.0$ & $600-900$ & $52-57$ & 1.19 \\
\hline
\end{tabular}


For carrying out researches on ion-exchange purification of syrups the pre-treatment of resins was carried out to the following scheme: soaking of resins in distilled water within $12 \mathrm{~h}$, further cation exchanger regeneration with $5 \%$ solution of the hydrochloric acid (3.0 vol/vol resins) for its transfer to $\mathrm{H}^{+}$form, an anionite with $4 \%$ solution of sodium hydroxide (3.0 vol/vol resins) to transfer to $\mathrm{OH}^{-}$form and washing with distilled water. A consumption of distilled water for washing from reagents for cation exchanger in $4 \mathrm{vol} / \mathrm{vol}$ resins, for anionite in $10 \mathrm{vol} / \mathrm{vol}$ resins. Thus prepared ion-exchange resins were used for refining the inulin containing syrups.

For additional refinement of inulin-containing syrups in the mixed bed of resins there were measured particular volumes of cation exchanger and an anionite. After soaking in water and regeneration they were mixed in a particular ratio of volumes and purification of syrup was carried out.

For additional purification of inulin syrup on sorbents Makronet of the polisher type after soaking the adsorbent was loaded into a column, washed with water and the syrup preliminary purified on a mixed bed of resins was passed.

Researches on ion-exchange purification of inulin-containing syrup showed that purification of the syrup in acidic medium on a strongly acid cation exchanger at $60^{\circ} \mathrm{C}$ promotes hydrolysis of an inulin with formation of 78.3-82.0 \% fructose depending on throughput rate of the syrup. In this regard to prevent hydrolysis of an inulin ion-exchange purification was carried out at a temperature no more than $35^{\circ} \mathrm{C}$.

The ion-exchange purification of inulin-containing syrup from a girasol and chicory was applied according to a two-level scheme $\mathrm{K} 1+\mathrm{A} 1+\mathrm{K} 2+\mathrm{A} 2$ with the use of ion-exchange resins to receive a powdery food inulin: a strongly acid cation exchanger $\mathrm{C} 150$, a weak-basic anionite A103S. To achieve a high degree purity of end products it was used additional ion-exchange purification on the mixed bed of resins: strongly acid cation exchanger PPC 150S and a strong-basic anionite A510SMB Plus, and also on an adsorbent of Makronet MN type (Figure 3).

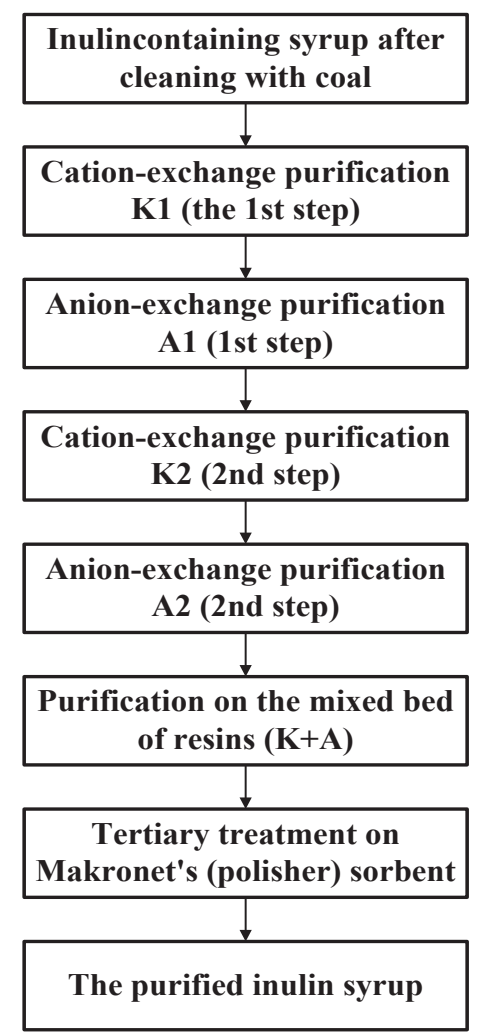

Figure 3. Process flow diagram of ion-exchange purification of inulin-containing syrup
For carrying out researches an extract and girasol and chicory syrups were received according to the earlier developed mode. Initial girasol syrup after purification with the fissile coal has a high chromacity of 3.20 units of an optical density and also contains the significant amount of protein $-4.50 \%$, ashes $-4.04 \%$. It is established that the mass fraction of protein in inulin-containing syrup from a girasol already decreases $2-3$ times after the 1 st step of purification on cation exchanger [13]. In general, after the 2nd step of purification indexes of syrup quality decrease in tens of times (Table 3). At the same time the carbohydrate composition of inulin-containing syrup from a girasol determined by a chromatographic method practically doesn't change.

Table 3

Indexes of quality of inulin-containing syrup from a girasol before and after ion-exchange purification

\begin{tabular}{|c|c|c|c|c|c|c|}
\hline 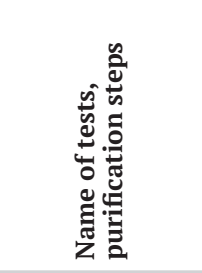 & 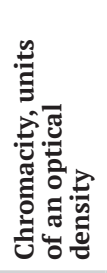 & 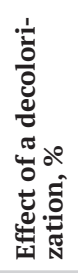 & 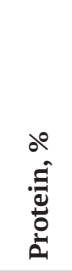 & 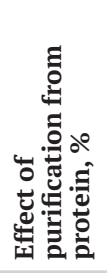 & 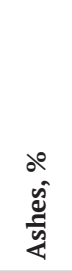 & 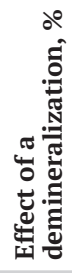 \\
\hline $\begin{array}{l}\text { Initial syrup for } \\
\text { purification }\end{array}$ & 3.20 & - & 4.50 & - & 4.04 & - \\
\hline $\mathrm{K}_{1}+\mathrm{A}_{1}+\mathrm{K}_{2}+\mathrm{A}_{2}$ & 0.32 & 90 & 0.5 & 89 & 0.12 & 97 \\
\hline
\end{tabular}

Ion-exchange purification of chicory inulin extract as well as a girasol one was carried out with use of ion-exchange resins of the Purolite company (USA) according to the above-stated scheme.

Results of researches (Table 4) show that purification of inulin-containing syrup from the chicory purified with the fissile coal with the following double ion-exchange purification has also high quality indexes, as well as for girasol syrup.

Indexes of quality of inulin-containing syrup from Table 4 chicory before and after ion-exchange purification

\begin{tabular}{|c|c|c|c|c|c|c|}
\hline 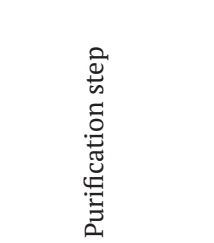 & 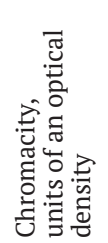 & 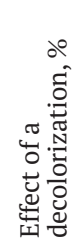 & 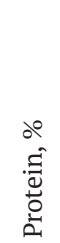 & 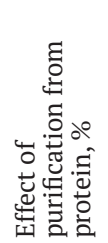 & $\begin{array}{l}\text { do } \\
\stackrel{0}{0} \\
\frac{\tilde{g}}{4}\end{array}$ & 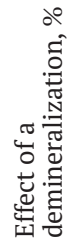 \\
\hline $\begin{array}{l}\text { Syrup for } \\
\text { purification }\end{array}$ & 1.16 & - & 4.2 & - & 5.10 & - \\
\hline After $\mathrm{K}_{1}-\mathrm{A}_{1}-\mathrm{K}_{2}-\mathrm{A}_{2}$ & 0.1 & 91.4 & 0,5 & 88 & 0.20 & 96 \\
\hline
\end{tabular}

It is established what at ion-exchange purification of inulincontaining syrup at a temperature not over $35^{\circ} \mathrm{C}$ its carbohydrate composition determined by a chromatographic method practically doesn't change. So, the carbohydrate composition of chicory (Table 5) practically didn't change in the course of ionexchange purification.

Table 5

Carbohydrate composition of chicory syrup before and after two-level ion-exchange purification Mass fraction of carbohydrates, \%

\begin{tabular}{|c|c|c|c|c|c|}
\hline Purification step & $\stackrel{\Xi}{\Xi}$ & 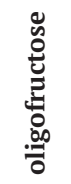 & 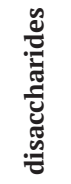 & 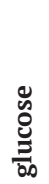 & 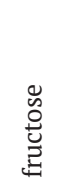 \\
\hline Initial crude extract & 82.09 & 3.52 & 8.73 & - & 5.65 \\
\hline After K1-A1-K2-A2 & 83.24 & 4.51 & 6.85 & - & 5.39 \\
\hline
\end{tabular}


Based on the conducted researches there are developed requirements to quality of inulin-containing syrup from a girasol and chicory after processing by the fissile coal and two-level ion-exchange purification of the syrup according to scheme $\mathrm{K} 1+\mathrm{A} 1+\mathrm{K} 2+\mathrm{A} 2$ with use of resins of cation exchanger $\mathrm{C} 150$ and an anionite A103S of the Purolyte company:

$\square \mathrm{pH}-4.5-7.0$;

$\square$ chromacity - no more than 0.4 conventional units of an optical density;

$\square$ mass of a protein fraction - no more than $0.5 \%$;

$\square$ mass of ashes fraction - no more than $0.2 \%$.

Thus, despite the increased impurity level of not carbohydrate character (the painting and mineral substances, protein) in girasol and chicory syrups the received results showed that at double ion-exchange purification it is possible to reduce the content of the mentioned impurity in tens of times.

The inulin-containing syrup purified on ion-exchange resins is concentrated further to a particular mass fraction of dry solids and dried up on a spray drier. The received inulin concentrate contains not less than $85 \%$ of an inulin, $12-14 \%$ of low-molecular carbohydrates, no more than $0.2 \%$ of ashes and $0.5 \%$ of protein and can be used as effective nutritional supplement. To receive a powdery inulin of higher purity and increased by degree and mass fraction of an inulin of $95 \%$ it is offered to use additional purification on ionites in the mixed bed and an adsorbent Makronet type MN 150 brand.

For additional purification inulin-containing syrup was passed through the mixed bed of resins of brands: PPS C150 cation exchanger and an anionite of A510 MBPlus in a particular volume ratio. Beforehand the optimum ratio of resins volume (cation exchanger - an anionite) - 1:2 was defined. It is established that after purification through the mixed bed of resins there is an additional purification of syrup: a chromacity decreases by 1.3 times, a mass fraction of protein - by 4.5 times.

The last stage of additional purification of syrup was carried out on adsorbents like Makronet by the brands MN 200 (neutral type) and MN 150 (strong-basic type). Preliminary researches showed that the adsorbent MN 502 (strongly acid type) was not suitable for purification of inulin-containing products at the last step because of his strongly acid type as the end product - inulin can be hydrolyzed in acidic medium. Researches showed that more effective purification happens on a sorbent like Makronet the brand MN 150: a chromacity decreases by 2.6 times, and a transparence - by 6.3 times. It is established for the first time that the bitter taste inherent in chicory syrup because of presence of a glycoside intibin is absent completely after cleaning on an adsorbent like Makronet.

The research of the purified inulin syrups in spectral range UF at $\lambda=280$ nanometers before and after purification (Figure 4 ) showed that the optical density at this wavelength after purification decreases by 10 times, i.e. colorants like oxymethylfurfurol (OMF) are adsorbed on a sorbent like Makronet.

Thus, after additional purification of inulin-containing syrup on the mixed bed of resins and an adsorbent a polisher MN 150 the following indexes of quality are received:

$\square \mathrm{pH}-4.5-7.0$;

$\square$ chromacity - no more than 0.1 units opt. square;

$\square$ mass of a protein fraction - no more than $0.2 \%$;

$\square$ mass of ashes fraction - no more than $0.2 \%$.

The developed universal technology of a girasol and chicory processing for an inulin includes the following stages: removing stones, sand and leafy tops of root vegetables from raw materials; washing; scalding; cutting to shaving; diffusion; coagulation; mechanical filtering; purification with the fissile coal and ion-exchange resins; cooking and drying of an inulin concentrate containing no more than $85 \%$ of an inulin. The powdery inulin with higher extent of purification and with not less than $95 \%$ of an inulin is received by additional ion-exchange purification, nanofiltration or a chromatography, with the subsequent cooking and drying. The choice of technology of an inulin depends on its required purity and also economic prerequisites $[7,8]$.

In the All-Russian Research Institute of Starch Products there are received samples of a powdery inulin and a dry concentrate of an inulin from inulin-containing raw materials. As control samples it was used an inulin from chicory of the Orafti and Cosucra companies (Belgium) and also an inulin from a girasol of the Bi Qing Yuman and XR XIRUI (PRCh) companies (Table 6). It is established that the mass fraction of an inulin in the samples is higher than $90 \%$, disaccharides of $4.59 \%$ to $7.83 \%$, fructose $-1.2 \%$. An index of solution specific rotation of the inulin containing $10 \%$ of dry solid $-[\alpha] d=10.95-$ $12.90 \mathrm{dg}$.

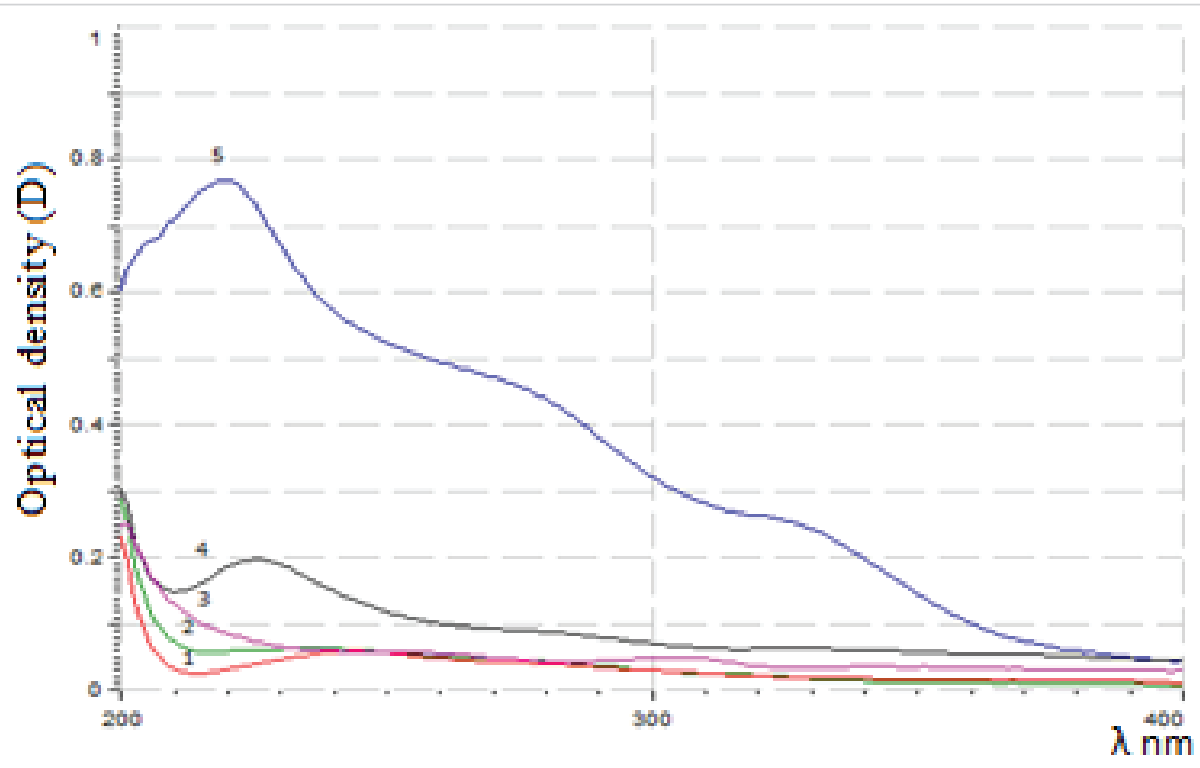

Figure 4. Dependence of an optical density (D) on a wavelength the inulin-containing syrups after purification: 1 - on the mixed bed (PPS C150 A510 MBPlus) + a polisher 150 (sample No. 1); 2 - on a polisher MN 150 (sample No. 2); 3 - on a polisher MN 200; 4 - on the mixed bed of resins; 5 - initial syrup after two-level ion-exchange purification 
Physical and chemical indicators of an inulin of the Orafti and Cosucra company (Belgium),

Table 6 Bi Qing Yuman, XR XIRUI (PRCh)

\begin{tabular}{|c|c|c|c|c|c|}
\hline \multirow{2}{*}{$\begin{array}{c}\text { Name of a sample, (raw materials, country } \\
\text { manufacturer) }\end{array}$} & \multirow{2}{*}{$\begin{array}{c}\mathrm{DS} \\
\%\end{array}$} & \multicolumn{3}{|c|}{ Carbohydrate composition, \% } & \multirow{2}{*}{$\begin{array}{c}\text { Specific rotation } \\
{[\alpha] \text { d, grad. (DS 10\%) }}\end{array}$} \\
\hline & & Inulin & Disaccharides & Fructose & \\
\hline Orafti GR inulin (chicory, Belgium) & 95.50 & 93.40 & 6.60 & - & -10.95 \\
\hline Fibruline Instant inulin & 94.85 & 94.25 & 4.59 & 1.16 & -12.90 \\
\hline (chicory, Belgium) & 97.40 & 94.30 & 5.70 & - & -11.6 \\
\hline Inulin (girasol, People’s Republic of China), Bi Qing Yuman & 97.40 & 90.46 & 7.83 & 1.71 & - \\
\hline
\end{tabular}

\section{Physical and chemical indexes of an inulin from a girasol and chicory}

Name of a sample, (raw materials, country manufacturer)

Inulin from a girasol (Kabardino-Balkaria, the Russian Federation)

Inulin from chicory (a variety «Yaroslavl», the Yaroslavl Region, the Russian Federation)
DS,

\section{$\%$}

94.84

Physical and chemical indexes of the samples of an inulin received from domestic inulin-containing raw materials (Table 7) differed on carbohydrate composition: a mass fraction of an inulin in a chicory sample made $87.84 \%$, disaccharides $-7.34 \%$, fructose $-4.80 \%$; and in an sample from a girasol respectively $-92.30 \%, 5.96 \%$ and $1.74 \%$.

\section{Conclusion}

The technological assessment of a girasol and chicory from various regions of the Russian Federation is carried out, their physical and chemical indexes are defined. It is offered to estimate the influence of a high-quality factor of inulin-containing raw materials when processing for an inulin by the following criteria: a mass fraction of dry solids and carbohydrates (an inulin, mono - and disaccharides). By results of researches initial requirements to technological behavior of raw materials while processing for an inulin are defined: a mass fraction of dry solids is not to be less than $25 \%$, an inulin - less than $16 \%$; mono and disaccharides $-2 \%$.

To prevent the increase in a chromacity of products when processing raw materials, especially a girasol for an inulin, various ways of its processing are offered: scalding of tubers, use of various reagents. It is established that sodium pyrosulphite solution used for processing of fresh cut shaving of a girasol and chicory in the course of processing and drying reduces its darkening. A chromacity of the extract from the processed shaving is $30 \%$ lower, than from the raw one, and the carbohydrate composition of the extract while processing practically doesn't change.

The technological mode of extraction of an inulin from inulin-containing raw materials is developed by hot water diffusion: hydromodule of crude shaving makes $1: 2$, of dry one is $1: 7$, temperature $-80-85^{\circ} \mathrm{C}$, the optimum length of $100 \mathrm{~g}$ of shaving $-10-20 \mathrm{~m}$.

During researches of shaving extracted from inulin-containing raw materials by the continuous hot water diffusion it is developed in essence new design of the diffusion device with
Specific rotation [a] d, grad. (DS 10\%)

\begin{tabular}{ccc}
\multicolumn{3}{c}{ Carbohydrate composition, \% } \\
Inulin & Disaccharides & Fructose \\
\hline 92.30 & 5.96 & 1.74 \\
87.84 & 7.36 & 4.80
\end{tabular}

an inclined screw unit, and a patent No. 2643243 «The diffusion device of the continuous action» of 31.01 .2018 is taken out by the Russian Federation.

Researches of ion-exchange purification of the inulin-containing syrups are conducted. Due to the lack of domestic production of ion-exchange resins for cleaning the inulin containing syrups their purification was carried out with resins of the Purolite company (USA) and also Makronet's sorbent MN-150.

Results of researches of double ion-exchange purification of syrups with use of strong acid cation exchanger C150 and a weakbasic anionite A103S showed the substantial increase of the product quality. There are developed requirements to quality of inulin-containing syrup from a girasol and chicory after processing by the fissile coal and two-level ion-exchange purification of syrup according to the scheme $\mathrm{K} 1+\mathrm{A} 1+\mathrm{K} 2+\mathrm{A} 2$ : a chromacity no more than 0.4 units of an optical density; a protein - no more than $0.5 \%$; ashes - no more than $0.2 \%$. However, the bitter flavor of an intibin inherent in chicory syrups, after ion-exchange cleaning doesn't disappear. It is established that additional purification of inulin-containing syrup from chicory on Makronet's adsorbent MN 150 allows to remove completely the bitter taste inherent in an intibin.

The technological mode of purification the inulin-containing syrups according to two-level scheme K1-A1-K2-A2, additional purification in the mixed bed of resins (strong acid cation exchanger PPC 150S and a strong-basic anionite of A510SMB Plus) and also on an adsorbent of Makronet type MN 150 is developed.

The carried-out proof tests of ion-exchange resins and adsorbents of the Purolite company showed that they can be used at the organization of inulin production.

\section{Acknowledgments}

Authors express gratitude for the provided being researched: samples of a girasol to heads of LLC VIVA (The Kostroma Region), of chicory to LLC Sovremennik, ion-exchange resins - to the staff of the Purolite company (USA).

\section{REFERENCES}

1. Kayshev, V.G., Lukin, N.D., Seryogin S.N. (2018). Organization of Inulin Production in Russia: Necessary Resources and Organizational and Economic Mechanism for Implementation this Priority Project. Economy of agricultural and processing enterprises, 6, 2-8. (in Russian)

2. Perkovets, M.V. (2007). Influence of inulin and oligofructose on decrease in risk of some «illnesses of civilization. Food industry, 5, 22-23. (in Russian)

3. Gulyuk, N.G, Lukin, N. D., Puchkova, T. S., Pikhalo, D. M., Karev Yu. P. (2016). The prospects of production and application of an inulin from a girasol: Thesis report YIII scientific and practical conference with the international participation «Commodity researcher 2016» subject «Problems of food supply in XXI century». M, 24-30. (in Russian)

4. Perkovets, M.V. (2004). Raftiline and Raftilose - ingredients for the functional food. Food industry, 8, 82-83. (in Russian)

5. GOST R 55757-2013 «Girasol (tubers). Landing material. Variety and landing qualities» Moscow: Standartinform. -2014. - 15 p. (in Russian)

6. Lukin, N.D., Ananskikh, V.V., Lapidus, T.V., Hvorova. L.S. (2007). Technological monitoring of production of sugary starch products: methodical manual. M, Russian Agricultural Academy. - 261 p. (in Russian) 
7. Gulyuk, N.G., Puchkova, T.S., Pikhalo, D.M., Gulakova, V. A. (2015). On Technology of Inulin Concentrate from Jerusalem Artichoke. Storage and processing of farm products, $12,37-39$. (in Russian)

8. Gulyuk, N.G., Lukin, N.D., Puchkova, T.S., Pikhalo, D.M. (2017). Processing of Inulin-conteining Raw Materials for Inulin and Its Derivatives. Achievements of Science and Technology of AIC, 31(8), 76-79. (in Russian)

9. Gulyuk N.G., Puchkova T.S., Pikhalo D.M., Gulakova V. A., Kovalyonok V. A. (2014). Study of diffusion of inulin from jerusalem artichoke tubers. Achievements of Science and Technology of AIC, 12, 67-69. (in Russian)

10. Ekutech R.I. (2010). Development of technology of receiving an inulin and food fibers from girasol tubers. Autoref. yew. Cand.Tech.Sci. Krasnodar, KUBGTU. -20 p. (in Russian)
11. Patent of the Russian Federation No. 2643243. Diffusion device of the continuous action 31.01.2018. Diffusion device of the continuous action / Gulyuk N.G., Lukin N.D., Ananskikh V.V., Puchkova T.S., Pikhalo D.M. Publ. 31.01.2018, Bulletin No. 4. (in Russian)

12. Gulyuk, N.G., Lukin, N.D., Puchkova, T.S., Pikhalo, D.M., Gulakova, V. A. (2017). About Clearing Extract of Inulin-Containing Raw. Food industry, 2, 24-26. (in Russian)

13. Puchkova, T.S., Pikhalo, D.M., Varitsev, P. Yu. (2018). The Use of Ion Exchange Resins in the Purification of Inulin-containing Jerusalem Artichoke (Helianthus tuberosus L.) Syrups. Food industry, 12, 38-42. (in Russian)

\section{AUTHOR INFORMATION}

Tatyana S. Puchkova - candidate of technical sciences, Leading Researcher, All-Russian Research Institute for Starch Products - Branch of V.M. Gorbatov Federal Research Center for Food Systems of RAS, 140051, Moscow region, Kraskovo, ul. Nekrasov, 11, Tel.:+7-495-557-15-00, e-mail: vniik@arrisp.ru Daniya M. Pikhalo - Senior Researcher, All-Russian Research Institute for Starch Products - Branch of V.M. Gorbatov Federal Research Center for Food Systems of RAS, 140051, Moscow region, Kraskovo, ul. Nekrasov, 11, Tel.: +7-495-557-15-00, e-mail: vniik@arrisp.ru *corresponding author

Oksana M. Karasyova - Junior Researcher, All-Russian Research Institute for Starch Products - Branch of V.M. Gorbatov Federal Research Center for Food Systems of RAS, 140051, Moscow region, Kraskovo, ul. Nekrasov, 11, Tel.: +7-495-557-15-00, e-mail: vniik@arrisp.ru Authors are equally relevant to the writing of the manuscript, and equally responsible for plagiarism The authors declare no conflict of interest

Received 24.05.2019 Accepted in revised 12.06.2019 Accepted for publication 21.06.2019 